\title{
Heavy Metal Contamination of Tree Leaves
}

\author{
Khageshwar Singh Patel1, Reetu Sharma', Nohar Singh Dahariya1, Ankit Yadav1, \\ Borislav Blazhev' ${ }^{2}$ Laurent Matini' ${ }^{3}$, Jon Hoinkis ${ }^{4}$ \\ ${ }^{1}$ School of Studies in Chemistry/Environmental Science, Pt. Ravishankar Shukla University, Raipur, India \\ ${ }^{2}$ Central Laboratory for Chemical Testing and Control, Sofia, Bulgaria \\ ${ }^{3}$ Department of Exact Sciences, E.N.S., Marien Ngouabi University, Brazzaville, Congo \\ ${ }^{4}$ Karlsruhe University of Applied Sciences, Karlsruhe, Germany \\ Email: patelkhageshwarsingh@gmail.com
}

Received 22 June 2015; accepted 25 July 2015; published 28 July 2015

Copyright (C) 2015 by authors and Scientific Research Publishing Inc.

This work is licensed under the Creative Commons Attribution International License (CC BY).

http://creativecommons.org/licenses/by/4.0/

c) (i) Open Access

\section{Abstract}

The study of heavy metal $\left(\mathrm{HM}_{\mathrm{s}}\right)$ contamination of environment is of great interest due to their serious health hazard. In this work, the contamination of tree leaves with the $\mathrm{HM}_{\mathrm{s}}$ in the most polluted industrial city, Korba, India is described. The leaves of common trees i.e. Azadirachta indica, Butea monosperma, Eucalyptus, Ficus religiosa, Mangifera indica and Tectona grandis were selected for assessment of the $\mathrm{HM}_{s}$ contamination as bioindicator. The elevated concentration of $\mathrm{HM}_{\mathrm{s}}$ (i.e. $\mathrm{As}, \mathrm{Fe}, \mathrm{Cr}, \mathrm{Mn}, \mathrm{Cu}, \mathrm{Zn}, \mathrm{Cd}, \mathrm{Pb}$ and $\mathrm{Hg}$ ) in the tree leaves was observed, ranging from 2.8 - 43, 728 - 5182, 8.6 - 49, 48 - 1196, $43-406,79-360,1.12-1.65,1.6-16.4$ and $0.13-0.76 \mathrm{mg} / \mathrm{kg}$, respectively. The concentration, enrichment and sources of the $\mathrm{HM}_{s}$ in the leaves are described. Azadirachta indica leaves, accumulating higher concentration of the $\mathrm{HM}_{\mathbf{s}}$, showed a higher efficiency as bioindicator for the urban pollution.

\section{Keywords}

Heavy Metal, Soil, Tree Leaf, Bioindicator, India

\section{Introduction}

The quality of environment (i.e. air, water and soil), microorganism activities, plant growth, etc. are affected by heavy metal $\left(\mathrm{HM}_{\mathrm{s}}\right)$ contaminations [1]-[3]. The woody plants are being excellent tool for biomonitoring of the metals due to rapid growth, high biomass, profuse root apparatus and low impact on the food chain and human health [4]-[9]. The accumulation of $\mathrm{HM}_{\mathrm{s}}$ in the tree leaves was reported to assess air quality and bioaccumula- 
tion fluxes [10]-[18]. The coal is widely used as source of energy in India and its huge exploitation causes the contamination of the environment [19]-[23]. In the present work, concentration, enrichment, and sources of the $\mathrm{HM}_{\mathrm{s}}$ (i.e. As, $\mathrm{Fe}, \mathrm{Cr}, \mathrm{Mn}, \mathrm{Cu}, \mathrm{Zn}, \mathrm{Cd}, \mathrm{Pb}$ and $\mathrm{Hg}$ ) in the dried leaves of common woody trees (i.e. Eucalyptus, Butea monosperma, Ficus religiosa, Tectona grandis and Azadirachta indica) in the largest coal burning basin, Korba, India are described as a bioindicator to assess the $\mathrm{HM}_{\mathrm{s}}$ contamination of the environment.

\section{Methods and Materials}

\subsection{Study Area}

The Korba coal basin, Chhattisgarh, India $\left(22^{\circ} 21^{\prime} \mathrm{N}, 82^{\circ} 40^{\prime} \mathrm{E}\right.$, above $>250 \mathrm{~m}$ from seas levels) was selected for the proposed investigation due to extreme environmental pollution. The area is covered by the dense tropical moist and deciduous forest dominated by trees i.e. Tectona grandis, Shorea Robusta, Pterocarpus marsupium, Anogeissus latifolia, Madhuca indica, Dendrocalamus strictus, Azadirachta indica, Butea monosperma, Eucalyptus, Ficus religiosa, Mangifera indica, etc. Several open and underground coal mines are in operation with production of $>10,000 \mathrm{MT} / \mathrm{Yr}$ coal. The most of electricity (40,000 MW) of the state is produced by the thermal power plants emitting effluents in the city. The Asia biggest aluminium plant with captive power plant of 1200 MW is also in operation. The population of city is $\approx 1$ million, being exposed with severs particulate and fly ash pollution.

\subsection{Collection of Soil and Plant Leaf Samples}

The sampling networks of soil and plant samples are shown in Figure 1. Leaves of six trees (i.e. Azadirachta indica, Butea monosperma, Eucalyptus, Ficus religiosa, Mangifera indica and Tectona grandis) of great social economic values were selected for this work. Azadirachta indica is a fast-growing broad-leaved evergreen large tree of India. The leaves have antibacterial and antiviral properties, and are often used in cosmetic and skin treatment preparations. Butea monosperma is a medium sized dry season-deciduous $\approx 15 \mathrm{~m}$ tall tree. The leaves are used as fodder for animals. Eucalyptus is quick growing tall tree with leaf of leathery in texture, hang obliquely and containing a fragrant volatile oil. Ficus religiosa is a large dry season-deciduous or semi-ever green tree up to $30 \mathrm{~m}$ tall with a large trunk with long and broad leaves. The Mangifera indica is a fruity tree with leafy green foliage of height ranging from $0.5-15 \mathrm{~m}$. Tectona grandis is a large deciduous tree having height up to $35 \mathrm{~m}$ with simple large leaves.

A $0.5 \times 5 \mathrm{~kg}$ of the surface soil samples $(0-10 \mathrm{~cm})$ from rhizospheric zone of five trees of each species was collected in January, 2013 from Manikpur, Korba as prescribed in the literature [24]. They were stored in polyethylene bottles and dried in an oven for overnight at $60^{\circ} \mathrm{C}$.

The leaves from five trees of each species ( $\geq 10$ Yrs old) were collected manually in January, 2013, washed thoroughly with deionized water and dried in a shed [25]. The samples were compressed into a powder with the help of a manual grinder and sieved out the particles of $\leq 1 \mathrm{~mm}$.

\subsection{Analysis}

The soil sample was mixed with deionised water into 1:2 (w/v) ratio in a 100-ml conical flask. The suspension was allowed to stand an overnight, and $\mathrm{pH}$ value of the extract was measured by Hanna $\mathrm{pH}$ meter type-HI991300.

A $0.25 \mathrm{~g}$ each of soil sample was digested with $8 \mathrm{ml}$ aqua regia in the closed microwave vessel for $15 \mathrm{~min}$. Similarly, $0.25 \mathrm{~g}$ dried leave sample was digested with $5 \mathrm{ml} \mathrm{HNO}_{3}+2 \mathrm{ml} \mathrm{H}_{2} \mathrm{O}_{2}$. An aliquot of the extract was diluted with deionized distilled water for further analysis. Similar procedure was applied for the digestion of the soil (NCS DC73382, Spex Certiprep, UK) and leaf (NIST-1515, USA) reference samples.

The Varian Liberty AX Sequential ICP-AES (plasma flow: $15 \mathrm{~L} / \mathrm{min}$, auxiliary flow: $1.5 \mathrm{~L} / \mathrm{min}$, power: $1 \mathrm{KW}$, PMT voltage: $650 \mathrm{~V}$ ) was used for analysis of the metals i.e. $\mathrm{Cr}, \mathrm{Mn}, \mathrm{Fe}, \mathrm{Cu}$ and $\mathrm{Zn}$. A VARIAN "SpectrAA 220Z" model graphite furnace atomic absorption spectrometer (GF-AAS) equipped with a longitudinal Zeeman effect background corrector and THGA tube, auto sampler and automatic data processor was employed for analysis of metals i.e. $\mathrm{Cd}$ and $\mathrm{Pb}$. The VARIAN "SpectraAA 55B equipped with hydride/cold vapour regenerator accessories was selected for analysis of elements i.e. As and Hg. The accuracy of the method for analysis of the metals $(n=3)$ in the reference materials was found to be $\leq 2 \%$. The precision of the analysis for the metals in soil and leaf samples was $\leq 5 \%$. 


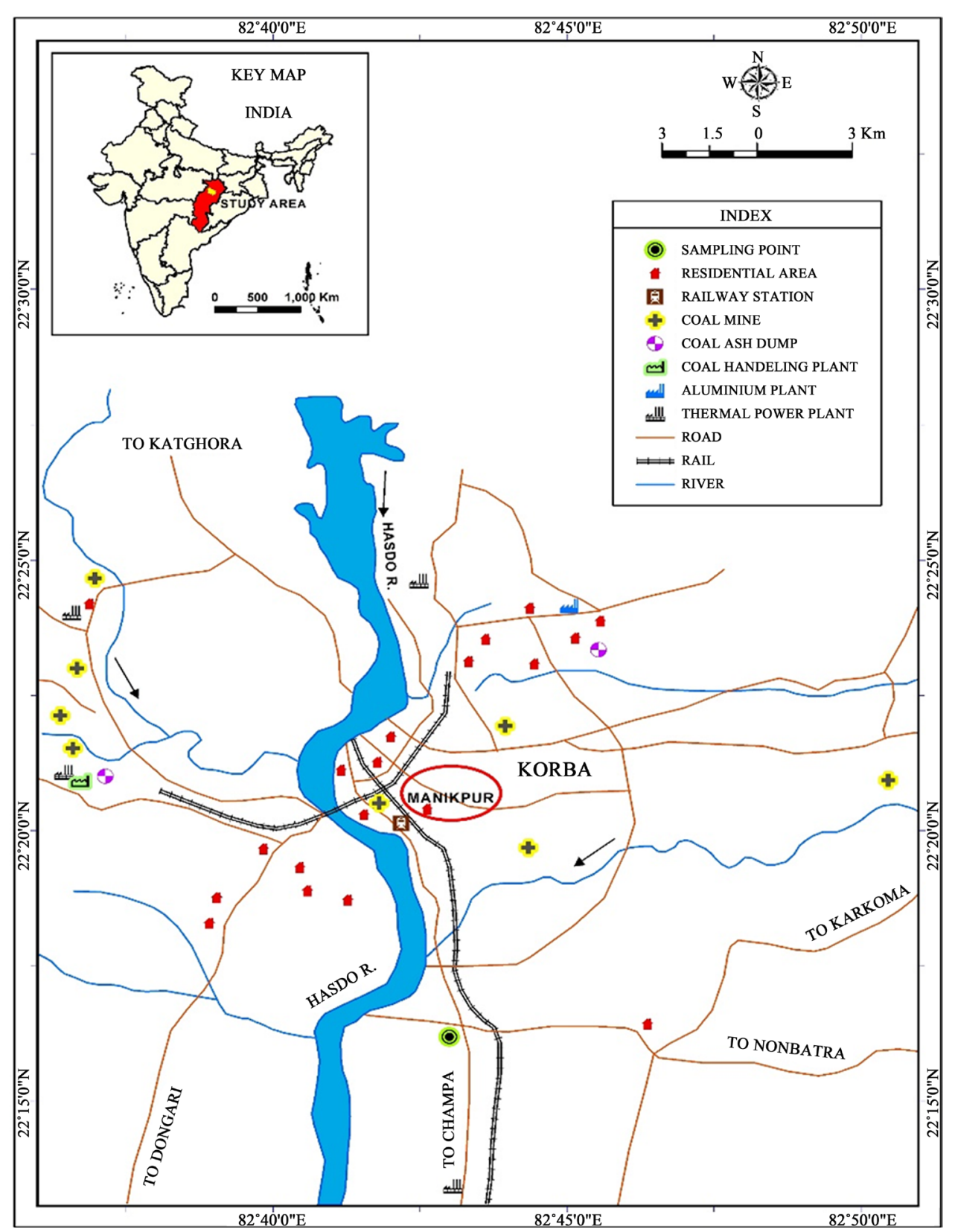

Figure 1. Representation of sampling location in Korba.

\subsection{Pollution Indices}

The enrichment factor $\left(E_{f}\right)$ is used to assess pollution of heavy metals in soil with respect to crustal contributions [26].

$$
E_{f}=\left(\left[C_{m}\right] /\left[C_{\mathrm{Al}}\right]\right)_{\text {soil }} /\left(\left[C_{m}\right] /\left[C_{\mathrm{Al}}\right]_{\text {cust }}\right)
$$

where, symbols $C_{m}$ and $C_{\mathrm{Al}}$ denote the concentration of the metal and aluminium in the soil and crust. The background concentration of $\mathrm{Al}, \mathrm{Fe}, \mathrm{As}, \mathrm{Cr}, \mathrm{Mn}, \mathrm{Cu}, \mathrm{Zn}, \mathrm{Cd}, \mathrm{Pb}$ and $\mathrm{Hg}$ in the earth crust reported was 81,500, 39,200, 4.8, 92, 775, 28, 67, 0.09, 17 and $0.05 \mathrm{mg} / \mathrm{kg}$, respectively [27]. Five contamination categories are generally recognized on the basis of the enrichment factor: $E_{f}<2$, depletion to mineral enrichment; $2 \geq E_{f}<5$, moderate enrichment; $5 \geq E_{f}<20$, significant enrichment; $20 \geq E_{f}<40$, very high enrichment; and $E_{f}>40$, extremely high enrichment [28]. 


\section{Results and Discussion}

\subsection{Concentration of Metals in Soils}

The physico-chemical characteristics of the rhizospheric soils are summarized in Table 1 . The soils were colored, ranging from brown to blackish. The $\mathrm{pH}$ value of the soil extract $(\mathrm{n}=6)$ was ranged from $6.2-7.2$ with mean value of $6.6 \pm 0.5$ at $95 \%$ probability. The concentration of As, $\mathrm{Cr}, \mathrm{Mn}, \mathrm{Fe}, \mathrm{Cu}, \mathrm{Zn}, \mathrm{Cd}, \mathrm{Pb}$ and $\mathrm{Hg}$ in the soil $(\mathrm{n}=6)$ was ranged from 10.8 - 20.0, 34 - 72, 314 - 1760, 17,718 - 45,426, 49 - 62, 26 - 62, 1.1 - 1.5, 19 - 48 and $1.2-2.0 \mathrm{mg} / \mathrm{kg}$ with mean value of $15.0 \pm 2.5,57 \pm 10,809 \pm 395,34,730 \pm 7462,55 \pm 4,43 \pm 10,1.3 \pm 0.1$, $33 \pm 8$ and $1.5 \pm 0.3 \mathrm{mg} / \mathrm{kg}$ at $95 \%$ probability, respectively. The mean $E_{f}$ value $(\mathrm{n}=6)$ for $\mathrm{Cr}, \mathrm{Zn}, \mathrm{Fe}, \mathrm{Mn}, \mathrm{Cu}$, $\mathrm{Pb}$, As, Cd and $\mathrm{Hg}$ was found to be 7, 7, 10, 12, 22, 22, 35, 161 and 337, respectively. The metals i.e. Cr, Zn, Fe and $\mathrm{Mn} ; \mathrm{Cu}, \mathrm{Pb}$ and $\mathrm{As}$; and $\mathrm{Cd}$ and $\mathrm{Hg}$ were significantly, highly and extremely enriched in the soil, respectively. The concentration of the $\mathrm{HM}_{\mathrm{s}}$ in the soil of Korba city was seen to be higher than reported in the soil of other region of the country, may be due to higher exploitation (i.e. mining and burning) of coal [21]-[23].

\subsection{Concentration of Metals in Leaves}

The concentration of HMs in the dried leaves is summarized in Table 2. High concentration of As, $\mathrm{Fe}, \mathrm{Cr}, \mathrm{Mn}$, $\mathrm{Cu}, \mathrm{Zn}, \mathrm{Cd}, \mathrm{Pb}$ and $\mathrm{Hg}$ in the tree leaves was observed, ranging from 2.8 - 43, 728 - 5182, 8.6 - 49, 48 - 1196, 43 - 406, 79 - 360, 1.12 - 1.65, $1.6-16.4$ and $0.13-0.76 \mathrm{mg} / \mathrm{kg}$, respectively. The highest content of all metals (except $\mathrm{Mn}, \mathrm{Cd}$ and $\mathrm{Hg}$ ) was marked with the Azadirachta indica leaves, may be due to bio-adsorption of the metals with the inherent alkaloids [29]. Similarly, the highest accumulation of metals i.e. Mn, Cd and Hg was observed in the Eucalyptus, Mangifera indica and Butea monosperma leaves, respectively, Table 2. The recommended values of $\mathrm{As}, \mathrm{Fe}, \mathrm{Cr}, \mathrm{Mn}, \mathrm{Cu}, \mathrm{Zn}, \mathrm{Cd}, \mathrm{Pb}$ and $\mathrm{Hg}$ in the vegetables were reported to be $0.1,425,2.3$, 500, 40, 100, 0.1, 0.2 and $0.03 \mathrm{mg} / \mathrm{kg}$, respectively [30]. Several folds higher concentration of metals i.e. As, Fe, $\mathrm{Cr}, \mathrm{Cu}, \mathrm{Cd}, \mathrm{Pb}$ and $\mathrm{Cd}$ than the recommended values was marked in all tree leaves. Extremely high $\mathrm{Mn}$ content in the Eucaliptus leaves was observed, being higher than recommended value of $500 \mathrm{mg} / \mathrm{kg}$.

The As content in the lichens of Mandav Monuments, India was reported maximum up to $51.95 \mathrm{mg} / \mathrm{kg}$ [10]. The content of $\mathrm{Cu}, \mathrm{Zn}, \mathrm{Cd}$ and $\mathrm{Pb}$ in leaves of natural and exotic plants of Samsun City, Turkey was ranged 40 60, $70-75,0.1-0.3$ and $12-35 \mathrm{mg} / \mathrm{kg}$, respectively [12]. The Mn content in leaf of holoptelia, cassia and neem trees of Gumgaon, India was reported in the range of $168.59-437.56 \mathrm{mg} / \mathrm{kg}$ [17]. The content of $\mathrm{Cu}, \mathrm{Pb}$ and $\mathrm{Cd}$ in the horse chestnut leaves at Studentski Park site was amounted to 110.2, 20.3 and $4.9 \mathrm{mg} / \mathrm{kg}$, respectively [18]. The $\mathrm{HM}_{\mathrm{s}}$ contents in the tree leaves of Korba city was found to be comparable with the values reported in other location of the country and World [10]-[12] [17] [18].

\subsection{Bioaccumulation of Metals in Leaves}

The bioaccumulation factor $\left(\mathrm{B}_{\mathrm{f}}\right)$ of the metals (ratio of leaf to soil content) in the leaves is presented in Table 3 . Significant $\mathrm{B}_{\mathrm{f}}$ value $(>1)$ of metals i.e. As, $\mathrm{Fe}, \mathrm{Cu}, \mathrm{Zn}$ and $\mathrm{Cd}$ in the Azadirachta indica leaves was observed. Similarly, high $\mathrm{B}_{\mathrm{f}}$ value $(>1)$ of $\mathrm{Zn}$ was marked in all tested leaves. The highest $\mathrm{BF}$ value for metals i.e. As, Fe, $\mathrm{Cr}, \mathrm{Cu}, \mathrm{Zn}$ and $\mathrm{Pb}$ was observed with the Azadirachta indica leaves, may be due to interaction of bioactive compounds (i.e. azadirachtin, nimbin, nimbidin and nimbolides). Significant $\mathrm{B}_{\mathrm{f}}$ value for $\mathrm{Mn}, \mathrm{Cd}$ and $\mathrm{Hg}$ was seen with Eucaliptus, M. Indica and B. Monosperma leaves, respectively. The results showed that the Azadirachta indica leaves are seemed to be a hyperaccumulator for five heavy metals i.e. As, Fe, $\mathrm{Cu}, \mathrm{Zn}$ and $\mathrm{Cd}$ in a huge coal burning area. Leaves of other trees i.e. M. Indica, Eucaliptus, B. Monosperma, F. Religiosa and T. Grandis were observed to be hyperaccumulator for heavy metals i.e. $\mathrm{Cu}, \mathrm{Zn}$ and $\mathrm{Cd}$, respectively. Among them, only Eucaliptus leaves was marked as good hyperaccumulator for Mn.

\subsection{Factor Analysis}

The result of factor analysis in tree leaves is given in Table 4. Three factors were extracted, and a $65.60 \%$ of the total variance was accounted by Factor-I. Six HMs i.e. $\mathrm{Cr}, \mathrm{Cu}, \mathrm{Fe}, \mathrm{Pb}, \mathrm{Zn}$ and As were positively correlated $(\mathrm{r}=$ $0.69-1.00$ ) to each other in the leaves, Table 5. A 13.90\% of the total variance was included in the Factor-II, and positively and negatively correlated with $\mathrm{Cd}$ and $\mathrm{Hg}$, suggesting aerial accumulation of $\mathrm{Hg}$ in the leaves rather than soil [31]. A $12.74 \%$ of the total variance was contributed by Factor-III, and is negatively correlated with Mn. 
Table 1. Physico-chemical characteristics of rhizospheric soil.

\begin{tabular}{|c|c|c|c|c|c|c|c|c|c|c|c|}
\hline \multirow{2}{*}{ Soil } & \multirow{2}{*}{ Color } & \multirow{2}{*}{$\mathrm{pH}$} & \multicolumn{9}{|c|}{ Mean value $(n=5) \mathrm{mg} / \mathrm{kg}$} \\
\hline & & & As & $\mathrm{Cr}$ & $\mathrm{Mn}$ & $\mathrm{Fe}$ & $\mathrm{Cu}$ & $\mathrm{Zn}$ & $\mathrm{Cd}$ & $\mathrm{Pb}$ & $\mathrm{Hg}$ \\
\hline $\mathrm{S} 1$ & $\mathrm{Br}$ & 6.96 & 15.5 & 59 & 749 & 33,818 & 50 & 36 & 1.31 & 36.2 & 1.37 \\
\hline $\mathrm{S} 2$ & $\mathrm{Bk}$ & 6.85 & 20.0 & 62 & 618 & 34,218 & 56 & 40 & 1.39 & 32.7 & 1.81 \\
\hline S3 & $\mathrm{Br}$ & 6.37 & 15.6 & 72 & 1760 & 38,499 & 56 & 44 & 1.38 & 47.7 & 1.71 \\
\hline $\mathrm{S} 4$ & $\mathrm{Bk}$ & 6.16 & 15.8 & 34 & 314 & 17,718 & 49 & 26 & 1.11 & 18.5 & 1.95 \\
\hline S5 & $\mathrm{Br}$ & 7.12 & 10.8 & 53 & 634 & 45,426 & 59 & 50 & 1.52 & 27.2 & 1.16 \\
\hline S6 & $\mathrm{Br}$ & 7.18 & 12.2 & 64 & 780 & 38,700 & 62 & 62 & 1.10 & 35.2 & 1.26 \\
\hline
\end{tabular}

$\mathrm{S}=$ Soil, $\mathrm{Br}=$ Brown, $\mathrm{Bk}=$ Blackish .

Table 2. Mean concentration $(n=5)$ of heavy metals in tree dried leaves, $\mathrm{mg} / \mathrm{kg}$.

\begin{tabular}{ccccccccccc}
\hline Plant & As & $\mathrm{Fe}$ & $\mathrm{Cr}$ & $\mathrm{Mn}$ & $\mathrm{Cu}$ & $\mathrm{Zn}$ & $\mathrm{Cd}$ & $\mathrm{Pb}$ & $\mathrm{Hg}$ \\
\hline Mangifera indica & 3.9 & 1570 & 9.5 & 302 & 77 & 86 & 1.65 & 3.3 & 0.17 \\
Eucaliptus & 2.8 & 728 & 8.6 & 1196 & 43 & 184 & 1.20 & 1.7 & 0.20 \\
Butea monosperma & 3.0 & 2400 & 14.6 & 343 & 55 & 86 & 1.15 & 1.6 & 0.76 \\
Ficus religiosa & 3.1 & 1700 & 21.3 & 58 & 48 & 83 & 1.12 & 1.8 & 0.17 \\
Tectona grandis & 6.4 & 2891 & 14.3 & 48 & 98 & 79 & 1.20 & 1.8 & 0.13 \\
Azadirachta indica & 43.1 & 5182 & 48.6 & 94 & 406 & 360 & 1.12 & 16.4 & 0.36 \\
\hline
\end{tabular}

Table 3. Mean bioaccumulation factor of metals in leaves.

\begin{tabular}{ccccccccccc}
\hline Plant & $\mathrm{As}$ & $\mathrm{Fe}$ & $\mathrm{Cr}$ & $\mathrm{Mn}$ & $\mathrm{Cu}$ & $\mathrm{Zn}$ & $\mathrm{Cd}$ & $\mathrm{Pb}$ & $\mathrm{Hg}$ \\
\hline Mangifera indica & 0.24 & 0.05 & 0.16 & 0.41 & 1.54 & 2.41 & 1.26 & 0.10 & 0.13 \\
Eucaliptus & 0.13 & 0.03 & 0.14 & 1.94 & 0.77 & 4.61 & 0.87 & 0.06 & 0.10 \\
Butea monosperma & 0.20 & 0.05 & 0.22 & 0.19 & 0.98 & 1.98 & 0.84 & 0.03 & 0.43 \\
Ficus religiosa & 0.20 & 0.10 & 0.62 & 0.19 & 0.98 & 3.17 & 1.01 & 0.10 & 0.10 \\
Tectona grandis & 0.59 & 0.05 & 0.27 & 0.08 & 1.66 & 1.58 & 0.78 & 0.06 & 0.10 \\
Azadirachta indica & 3.54 & 1.33 & 0.76 & 0.11 & 6.55 & 5.80 & 1.01 & 0.48 & 0.36 \\
\hline
\end{tabular}

Table 4. Results of factor analysis of heavy metals in the tree leaves.

\begin{tabular}{|c|c|c|c|}
\hline Variable & Factor-I & Factor-II & Factor-III \\
\hline $\mathrm{Cd}$ & -0.35 & 0.79 & 0.03 \\
\hline $\mathrm{Cr}$ & 0.93 & -0.12 & 0.30 \\
\hline $\mathrm{Cu}$ & 0.97 & 0.06 & 0.21 \\
\hline $\mathrm{Fe}$ & 0.83 & -0.15 & 0.50 \\
\hline Mn & -0.16 & -0.02 & -0.98 \\
\hline $\mathrm{Pb}$ & 0.97 & 0.09 & 0.15 \\
\hline $\mathrm{Zn}$ & 0.97 & 0.00 & -0.23 \\
\hline $\mathrm{Hg}$ & -0.37 & -0.75 & 0.03 \\
\hline As & 0.98 & 0.02 & 0.17 \\
\hline Eigenvalue & 5.90 & 1.25 & 1.15 \\
\hline$\%$ Variance & 65.60 & 13.90 & 12.74 \\
\hline \% Cumulative Variance & 65.60 & 79.49 & 92.23 \\
\hline
\end{tabular}

Loading value $>0.70$, significant at $\mathrm{p}<0.05$. 
Table 5. Correlation matrix of $\mathrm{HM}_{\mathrm{s}}$ in the tree leaves.

\begin{tabular}{|c|c|c|c|c|c|c|c|c|c|}
\hline & Cd & $\mathrm{Cr}$ & $\mathrm{Cu}$ & $\mathrm{Fe}$ & Mn & $\mathrm{Pb}$ & $\mathrm{Zn}$ & $\mathrm{Hg}$ & As \\
\hline $\mathrm{Cd}$ & 1.00 & & & & & & & & \\
\hline $\mathrm{Cr}$ & -0.44 & 1.00 & & & & & & & \\
\hline $\mathrm{Cu}$ & -0.24 & 0.94 & 1.00 & & & & & & \\
\hline $\mathrm{Fe}$ & -0.35 & 0.90 & 0.92 & 1.00 & & & & & \\
\hline $\mathrm{Mn}$ & 0.06 & -0.46 & -0.35 & -0.60 & 1.00 & & & & \\
\hline $\mathrm{Pb}$ & -0.19 & 0.94 & 0.99 & 0.86 & -0.29 & 1.00 & & & \\
\hline $\mathrm{Zn}$ & -0.32 & 0.84 & 0.90 & 0.69 & 0.07 & 0.92 & 1.00 & & \\
\hline $\mathrm{Hg}$ & -0.19 & -0.27 & -0.34 & -0.14 & 0.10 & -0.33 & -0.33 & 1.00 & \\
\hline As & -0.28 & 0.95 & 1.00 & 0.90 & -0.32 & 0.99 & 0.92 & -0.33 & 1.00 \\
\hline
\end{tabular}

\section{Conclusion}

The soil of the Korba city, India is highly polluted with $\mathrm{As}, \mathrm{Cu}, \mathrm{Pb}$ and $\mathrm{Hg}$ due to coal burning and mining. The highest phytoextraction of the $\mathrm{HM}_{\mathrm{s}}$ was observed with Azadirachta indica leaves; it may be due to interaction of the alkaloids with the metals. Significant $\mathrm{B}_{\mathrm{f}}$ values $(>1)$ for metals i.e. As, $\mathrm{Cu}$ and $\mathrm{Zn}$ with the Azadirachta indica leaves were marked. The Azadirachta indica leaves could be considered as bioindicator for soil pollution of the $\mathrm{HM}_{\mathrm{s}}$ in the coal burning area of the country.

\section{Acknowledgements}

We are thankful to the Alexander von Humboldt Foundation, Bonn, Germany for granting financial support to one of the author: KSP.

\section{References}

[1] Järup, L. (2003) Hazards of Heavy Metal Contamination. British Medical Bulletin, 68, 167-182. http://dx.doi.org/10.1093/bmb/ldg032

[2] Singh, J. and Kalamdhad, A.S. (2011) Effects of Heavy Metals on Soil, Plants, Human Health and Aquatic Life. International Journal of Research in Chemistry and Environment, 1, 15-21.

[3] Wang, L.K., Chen, J.P., Hung, Y.T. and Shammas, N.K. (2009) Handbook on Heavy Metals in the Environment. CRC Press, Boca Raton.

[4] Estrabou, C., Filippini, E., Soria, J.P., Schelotto, G. and Rodriguez, J.M. (2011) Air Quality Monitoring System Using Lichens as Bioindicators in Central Argentina. Environmental Monitoring and Assessment, 182, 375-383. http://dx.doi.org/10.1007/s10661-011-1882-4

[5] Kovalchuk, O., Titov, V., Hohn, B. and Kovalchuk, I. (2001) A Sensitive Transgenic Plant System to Detect Toxic Inorganic Compounds in the Environment. Nature Biotechnology, 19, 568-572. http://dx.doi.org/10.1038/89327

[6] Singh, M., Goel, P. and Singh, A.K. (2005) Biomonitoring of Lead in Atmospheric Environment of an Urban Center of the Ganga Plain, India. Environmental Monitoring and Assessment, 107, 101-114. http://dx.doi.org/10.1007/s10661-005-2146-y

[7] Stankovic, S. and Stankovic, A.R. (2013) Chapter 5: Bioindicators of Toxic Metals. In: Lichtfouse, E., Schwarzbauer, J. and Robert, D., Eds., Green Materials for Energy, Products and Depollution, Series Volume 3, Springer Netherlands, 151-228.

[8] Temmerman, L.D., Nigel, J., Bell, B., Garrec, J.P., Klumpp, A., Krause, G.H.M. and Tonneijck, A.E.G. (2005) Biomonitoring of Air Pollutants with Plants. Environmental News Archives, 11, 5-6.

[9] Tomaševič, M., Vukmirovič, Z., Rajšič, S., Tasič, M. and Stevanovič, B. (2008) Contribution to Biomonitoring of Some Trace Metals by Deciduous Tree Leaves in Urban Areas. Environmental Monitoring and Assessment, 137, 393-401. http://dx.doi.org/10.1007/s10661-007-9775-2

[10] Bajpai, R., Upreti, D.K. and Dwivedi, S.K. (2009) Arsenic Accumulation in Lichens of Mandav Monuments, Dhar District, Madhya Pradesh, India. Environmental Monitoring and Assessment, 159, 437-442. http://dx.doi.org/10.1007/s10661-008-0641-7

[11] Bashmakov, D.I. and Lukatkin, A.S. (2002) Accumulation of Heavy Metals by Some Higher Plants under Different 
Habitat Conditions. Agrochemistry, 9, 66-71.

[12] Demirayak, A., Kutbay, H.G., Kilic, D., Bilgin, A. and Hüseyinova, R. (2011) Heavy Metal Accumulation in Some Natural and Exotic Plants in Samsun City. Ekoloji, 20, 1-11.

[13] Liu, Y.J., Zhu, Y.G. and Ding, H. (2007) Lead and Cadmium in Leaves of Deciduous Trees in Beijing, China: Development of a Metal Accumulation Index (MAI). Environmental Pollution, 145, 387-390. http://dx.doi.org/10.1016/j.envpol.2006.05.010

[14] Massadeh, A.M., Jaradat, Q.M., Momani, K.A. and Saleem, M.A. (2009) Distribution of Heavy Metals in Some Tree Leaves along the Main Road in an Agricultural Area. Communications in Soil Science and Plant Analysis, 40, 12541267. http://dx.doi.org/10.1080/00103620902754622

[15] Nayaka, N., Upreti, D.K., Gadgil, M. and Pandey, V. (2003) Distribution Pattern and Heavy Metal Accumulation in Lichens of Bangalore City with Special Reference to Lalbagh Garden. Current Science, 84, 674-680.

[16] Piczak, K., Leśniewicz, A. and Żyrnicki, W. (2003) Metal Concentrations in Deciduous Tree Leaves from Urban Areas in Poland. Environmental Monitoring and Assessment, 86, 273-287. http://dx.doi.org/10.1023/A:1024076504099

[17] Raju, D., Kumar, S., Mehta, U.J. and Hazra, S. (2008) Differential Accumulation of Manganese in Three Mature Tree Species (Holoptelia, Cassia, Neem) Growing on a Mine Dump. Current Science, 94, 639-643.

[18] Tomaševic, M., Rajšic, S., Dorđević, D., Tasić, M., Krstić, J. and Novaković, V. (2004) Heavy Metals Accumulation in Tree Leaves From Urban Areas. Environmental Chemistry Letters, 2, 151-154. http://dx.doi.org/10.1007/s10311-004-0081-8

[19] Guttikunda, S.K. and Jawahar, P. (2014) Atmospheric Emissions and Pollution from the Coal-Fired Thermal Power Plants in India. Atmospheric Environment, 92, 449-460. http://dx.doi.org/10.1016/j.atmosenv.2014.04.057

[20] Sheoran, V., Sheoran, A.S. and Tholia, N.K. (2011) Acid Mine Drainage: An Overview of Indian Mining Industry. International Journal of Earth Sciences and Engineering, 4, 1075-1086.

[21] Mandal, A. and Sengupta, D. (2006) An Assessment of Soil Contamination Due to Heavy Metals Around a Coal-Fired Thermal Power Plant in India. Environmental Geology, 51, 409-420. http://dx.doi.org/10.1007/s00254-006-0336-8

[22] Sengupta, S., Chatterjee, T., Ghosh, P.B. and Saha, T. (2010) Heavy Metal Accumulation in Agricultural Soils Around a Coal Fired Thermal Power Plant (Farakka) in India. Journal of Environmental Science and Engineering, 52, 299-306.

[23] Singh, R., Singh, D.P., Kumar, N., Bhargava, S.K. and Barman, S.C. (2010) Accumulation and Translocation of Heavy Metals in Soil and Plants from Fly Ash Contaminated Area. Journal of Environmental Biology, 31, 421-430.

[24] Tan, K.H. (2005) Soil Sampling, Preparation, and Analysis. 2nd Edition, CRC Press, Boca Raton.

[25] Kalra, Y.P. (1998) Handbook of Reference Methods for Plant Analysis. CRC Press, Boca Raton.

[26] Sinex, S.A. and Helz, G.R. (1981) Regional Geochemistry of Trace Elements in Chesapeake Bay Sediment. Environmental Geology, 3, 315-323. http://dx.doi.org/10.1007/BF02473521

[27] Rudnick, R.L. and Gao, S. (2003) Composition of the Continental Crust. In: Holland, H.D. and Turekian, K.K., Eds., The Crust: Treatise on Geochemistry, Elsevier-Pergamon, Oxford, 3, 1-64.

[28] Sutherland, R.A. (2000) Bed Sediment Associated Trace Metals in an Urban Stream, Oahu, Hawaii. Environmental Geology, 39, 611-627. http://dx.doi.org/10.1007/s002540050473

[29] Sharma, A. and Bhattacharyya, K.G. (2005) Azadirachta indica (Neem) Leaf Powder as a Biosorbent for Removal of Cd(II) from Aqueous Medium. Journal of Hazardous Materials, 125, 102-112. http://dx.doi.org/10.1016/j.jhazmat.2005.05.012

[30] Codex Alimentarius Commission (FAO/WHO) (2001) Food Additives and Contaminants. Joint FAO/WHO Food Standards Programme, ALINORM 01/12A, 1-2892001.

[31] Niu, Z., Zhang, X., Wang, S., Ci, Z., Kong, X. and Wang, Z. (2013) The Linear Accumulation of Atmospheric Mercury by Vegetable and Grass Leaves: Potential Biomonitors for Atmospheric Mercury Pollution. Environmental Science and Pollution Research International, 20, 6337-6343. http://dx.doi.org/10.1007/s11356-013-1691-0 